\title{
THE IMPACTS OF EU COHESION POLICY FUNDING ON THE BULGARIAN ECONOMY
}

\author{
D. Deleva* \\ Evro Invest Consult Deleva LTd, Stara Zagora, Bulgaria
}

\begin{abstract}
The purpose of this report is to show the development of the European Cohesion Funding Policy, its main levers and instruments in Bulgaria, to look at the main strands, the planned and paid subsidies. Statistical and comparative methods are used. Through them are presented the results achieved in Bulgaria. The conclusions are that European Cohesion Funds are very importand for the development of the Bulgarian economy and continue to be a key factor in it. The membership of Bulgaria in the European Union has positively influenced the development of the Bulgarian economy.
\end{abstract}

Key words: EU funds, Bulgaria, growing, results

\section{INTRODUCTION}

This year we have already celebrated 10 years of Bulgaria's membership in the European Union. This period is sufficient to make a realistic analysis of the benefits of our membership.

The types of mechanisms for influencing European policy are administrative and financial. Here will be examined the financial mechanisms of the European Union, which are the European Regional Development Fund and the European Social Fund, also known as the Structural Funds and the Cohesion Fund. The Cohesion Fund budget for the entire European Union for the period 2007-2013 is $€ 347$ billion.

The aim of cohesion policy is to strengthen equality in the Union through economic, social and territorial cohesion by reducing the gap between the levels of development of the different regions and countries. At the same time, it is at the heart of efforts to improve the competitive position of the EU as a whole and its poorest regions in particular.

\section{Analysis of the overall assimilation of European funds \\ European investments in Bulgaria for the period 2007-2013 are 6.9 billion euro. They are divided into seven different Programs:"Administrative Capacity",}

*Correspondence to: Dora Deleva, Evro Invest Consult DelevaLTd, Stara Zagora, Zar Ivan Shishman, 77, Mobile: 0898266999, dora_deleva@yahoo.de
"Competitiveness", "Environment", "Human Resources", "Regional Development", "Transport" and "Technical Assistance" and two Programs funded by the European

Agricultural Fund for Rural Development and the European Fisheries Fund - "Rural Development Program 2007-2013" and the "Operational Program for the Development of the Fisheries Sector 2007-2013".

The Cohesion Policy Priorities in Bulgaria are:

- Improving transport infrastructure and access to all areas - EUR 2 billion (accounting for $30 \%$ of the total allocation), because the transport infrastructure in Bulgaria is underdeveloped and this has a strong impact on the inequality of the regions.

- Research and innovation - 850 million Euros. The share of innovative enterprises and innovations in manufacturing is low, and this is one of the key factors for rapid pace of economic development.

- Business support - 200 million Euros. Direct business financing contributes to increased cohesive rates and approximation to European production standards and added value.

- Contemporary broadband connectivity and e-services - $€ 67$ million Euros. This funding is a key factor for the development of all sectors of the economy

- Employment measures - 370 million Euros. There are relatively high unemployment rates in some sensitive population groups, 
such as youth and minorities and this funding aims to break these inequalities.

- Environmental, risk and energy projects 2.8 billion Euros (42\% of allocations). Nature conservation, green energy and the prevention of risks are important for the future development of the economy in the long run.

\section{Expectations, reality and progress made by Bulgaria on the assimilation of European funds}

- OP Transport 2007-2013 - the verified costs BGN 3208110 460, which represents $85.83 \%$ of the budget

- OP "Regional Development" 2007-2013 the total sums paid to the beneficiaries currently amount to BGN 3058819620 , representing $97,67 \%$ of the OP budget

- OP "Environment 2007-2013" - the total disbursed funds of the beneficiaries amounted to BGN 3505279 123, which is $109,17 \%$ of the OP budget

- OP "Human Resources Development" 2007-2013. - the beneficiaries have been paid $2279726431 \mathrm{BGN}$, which is $96.02 \%$ of the total budget of the program

- OP "Development of the Competitiveness of the Bulgarian Economy" 2007-2013 The amounts actually paid to the beneficiaries are BGN 2172077 359, representing $95,56 \%$ of the program budget

- OP "Administrative Capacity" 2007-2013 the amounts paid to beneficiaries 331878 076 BGN, which represents $97.49 \%$ of the budget

- OP "Technical Assistance" 2007-2013 paid BGN 106679 997, which represents $99.79 \%$ of the program budget

- Rural Development Program 2007-2013 - a total of BGN 6010249215 or $99.04 \%$ of the RDP budget

- Development of the Fisheries sector 20072013 - certifies total public expenditure amounting to BGN 135595784,38

The envisaged total funding for Bulgaria was amounted to BGN 22468941703 . The total funding achieved for the 2007-2013 programming period amounts to BGN 21570 389178 or is equal to $91,88 \%$ of total amount. If we only look at the percentage dimension, Bulgaria's progress is very high. It should be borne in mind that Bulgaria has no experience with such large-scale financing.

To make a more accurate assessment of the impact of Cohesion Funds, should be considered the macroeconomic effects of the EU's financial instruments in Bulgaria. It is not enough to highlight the results achieved in the area of absorption of EU funds during the first programming period 2007-2013. Their impact on key macroeconomic indicators has to be assessed too. This assessment is most representative when using the econometric SIBILA model, version 2.01, which allies the consequences of the entry of EU funds into the economy by distinguishing short-term and supply-side effects from the supply side. SIBILA has a medium till long-term character, therefore has both Keynesian and Neoclassic Characteristics. The effects are presented as the difference between the functioning of the economy in a basic model without European founds and an alternative model in which the European founds of economic integration are represented. SIBILA stands for Simulation (model) of Bulgaria's Investment in LongTerm Advance.

The model presents demand and supply. Demand is expressed by changes in consumption and investments (private and public). A production function is created for the supply. Long - term growth is a technological change, which depends on the model, infrastructure costs, ICT and R \& D expenditure. The short - term (until equilibrium) growth is generated by physical capital, labor and human capital. Demand is modeled from the point of view of GDP by components of end use: Consumption (private and public), Investment (private and public), Export of goods and services, Import of goods and services. The interest rates in the model are equal to the return on capital. Consumer prices depend on International prices and labor productivity.

The model evaluates the long-term factors like Economic growth - the effects of investment in human Capital, ICT, R \& D, infrastructure and physical capital with components fully adapted to the specifics of the Bulgarian economy and evaluates the net effects of a separate operational program, or a combination of programs, as well as a separate priority or a combination of priorities or procedures. The main objective of the model is to assess the effects of European funds on the Bulgarian economy.

The project was completed in 2011 by the Consortium "ECORIS - PPS - NEWS" with team Stefan Cvetkov, Dimitar Vassilev, Kaloyan Ganev, Ralitsa Simeonova-Ganeva, Petar Chobanov on Project "Development of an econometric model for impact assessment of The Structural and Cohesion Funds of the European Union "under Project No 0018-CIO- 
3.2. "Developing an Impact Assessment Model for SCF", Financed under the Operational Program "Technical Assistance." The documentation for the project is published on www.eufunds.bg / document / 3428.

At the entrance there are evaluated the four main sectors of the economy - real, monetary, fiscal and external. Three additional blocks have been built, dealing with the accumulation of human capital, infrastructure and technology. It works with 170 equations and 202 variables. For the analysis of the effects of EU funds, the economy is divided into four groups: Agriculture and Forestry, Industry, Construction, Services.

The difference between the results of the baseline and the alternative scenario with respect to an economic indicator measures the net impact of European funds.

The simulation model SIBILA 2.0 requires allocation of entry costs (European Funds and corresponding national co-financing) by basic economic categories: capital, technology, human capital, labor, infrastructure capital.

Effects of the implementation of investment costs under the European Funds for the 2007-2013 programming period

Table 1.

\begin{tabular}{|l|l|}
\hline Macroeconomic Indicator & Effect to 2016 \\
\hline GDP & $11.5 \%$ \\
\hline Export of goods and services & $1.7 \%$ \\
\hline Import of goods and services & $7.8 \%$ \\
\hline Current account,\% of GDP & $-1.4 \mathrm{p} . \mathrm{p}$. \\
\hline Private consumption & $13.9 \%$ \\
\hline Private investment & $22.3 \%$ \\
\hline Employment (15-64 years) & $15.2 \%$ \\
\hline Unemployment rate (15-64 years) & $-6.5 \mathrm{p} . . \mathrm{p}$ \\
\hline Average salary & $14.9 \%$ \\
\hline HICP inflation & $4.6 \%$ \\
\hline Budget balance,\% of GDP & $2.1 \mathrm{p} . \mathrm{p} .$. \\
\hline
\end{tabular}

Source: Ministry of Finance,SIBILA2.0

The effect on the added value of realized investments is positive. There is a cumulative increase of $11.5 \%$ of GDP towards the end of 2016 over the baseline scenario without European funding. This is mainly due to the positive effects of government spending on production in the country, and hence on changes in private consumption and investment.

As a large part of the measures under the Operational Programs are dedicated to investment activity, the cumulative increase in the volume of private investments is observed by $22.3 \%$ towards the end of 2016 , and this is one of the most important effects of the assimilation of European funds .

Another very important effect for the economy is the reduction of unemployment and the increase of employment.

Higher labor demand as a result of the absorbed funds also affects the level of pay, which also explains the positive dynamics of private consumption.

\section{CONCLUSION}

The strong positive impact of the European funds leads to an increase in the competitiveness of the Bulgarian economy in both- the short and the long term. This in turn is the desired influence and expected impact on the Cohesion Funds on the Bulgarian economy.

The aggregate of the examined macroeconomic indicators clearly shows the beneficial impact of the European financing for Bulgaria on the road of the European integration and development and assesses the absorption and positive results achieved by the Cohesion Policy of the EU.

The significant progress for Bulgaria over the period 2007-2013 regarding the absorption of European funds and their great impact on the Bulgarian economy is close to the goals of a united Europe. In the coming 2014-2020 
period, the Union's objectives are expanding, with more money being spent on innovation, energy independence and efficiency, and direct business financing. With the experience we already have till now, Bulgaria has a real chance to fully absorption of all resources and makes use of the opportunities provided by Cohesion Policy of the European Union.

\section{REFERENCES}

1. Bradley J., Fitzgerald J., 1988, Industrial Output and Factor Input determination in an Econometric Model of a Small Open Economy", European Economic Review, 32, pp. 1227-41

2. Ederveen, S., de Groot H.L.F., and Nahuis, R., 2002, "Fertile Soil for Structural Funds? A Panel Data Analysis of the Conditional Effectiveness of European Cohesion Policy”, Issue 10 of CPB Netherlands Bureau of Economic Policy Analysis

3. COMMITTEE ON EUROPEAN AFFAIRS AND MONITORING OF THE EUROPEAN FUNDS, Annual report, March,.2016

4. Mitra, Pritha and Cyril Pouvelle, 2012, "Productivity Growth and Structural Reform in Bulgaria: Restarting the Convergence Engine", IMF Working Paper WP/12/131, International Monetary Fund, Washington DC.

5. Rosenberg Ch.and Sierhej R, 2007, "Interpreting EU Funds Data for
Macroeconomic Analysis in the New Member States", IMF Working Paper WP/07/77, International Monetary Fund, Washington DC.

6. Varga, J., in 't Veld, 2010, "The Potential Impact of EU Cohesion Spending in the 2007-13 Programming Period: A ModelBased Analysis", European Economy Economic Paper, No. 422, Brussels

7. Beauvais,C., Jenson, J., Social Cohesion: Updating the State of the Research, Canadian Policy Research Networks Inc., Ottawa, 2002, p. 2.

8. COUNCIL OF MINISTERS of Bulgaria, Supporting the process of drafting the Partnership Contract of the Republic of Bulgaria outlining the assistance under the Common Strategic Framework (CSF) for the period 2014-2020 under Project No 0094-CCP-1.1. "Supporting the overall process of drafting the Partnership Contract of the Republic of Bulgaria for the period 2014-2020", financed under Operational Program "Technical Assistance", Consortium "WIG and PARTNERS", 2012

9. INSTITUTE FOR ECONOMIC RESEARCH AT BAS, K. Ganev, R. Simeonova, "Do economic policies have an impact on growth?- a model for assessing the impact of European Funds on the Bulgarian economy (SIBILA) " 